\title{
Characteristics of a Logistics-Based Business Model
}

\author{
Erik Sandberg, Tobias Kihlén and Mats Abrahamsson
}

\section{Linköping University Post Print}

\section{Tweet}

N.B.: When citing this work, cite the original article.

Original Publication:

Erik Sandberg, Tobias Kihlén and Mats Abrahamsson, Characteristics of a Logistics-Based Business Model, 2011, Journal of Marketing Channels, (18), , 1-23.

http://dx.doi.org/10.1080/1046669X.2011.558829

Copyright: Taylor and Francis

Postprint available at: Linköping University Electronic Press

http://urn.kb.se/resolve?urn=urn:nbn:se:liu:diva-66111 
Characteristics of a Logistics-Based Business model

\title{
Cover page
}

Title: Characteristics of a Logistics-Based Business Model

Submitted 8 September 2010 to Journal of Marketing Channels

By: Erik Sandberg*, Tobias Kihlén and Mats Abrahamsson

\begin{abstract}
In companies where excellence in logistics is decisive for the outperformance of competitors, and logistics has an outspoken role for the strategy of the firm, there is present what we refer to here as a "logistics-based business model". Based on a multiple case study of three Nordic retail companies, the purpose of this article is to explore the characteristics of such a logisticsbased business model. As such, this research helps to provide structure to logistics-based business models and identifies a way forward for companies for whom logistics and distribution is a major concern for the overall strategy of the firm.
\end{abstract}

Key words Business models, strategic management theory, multiple case study

Paper type Research paper

\section{Contact details}

Erik Sandberg*, Assistant Professor

Logistics Management, Department of Management and Engineering,

Linköping Institute of Technology, Sweden

Tel: +46-(0)13-28 44 92, Email: erik.sandberg@liu.se

Tobias Kihlén, Ph.D.

Accenture Management Consulting, Process \& Innovation Performance

Stockholm, Sweden

Tel: +46-(0)8-451 34 46, Email: tobias.kihlen@accenture.com

Mats Abrahamsson, Professor

Logistics Management, Department of Management and Engineering,

Linköping Institute of Technology, Sweden

Tel: +46-(0)13-28 15 11, Email: mats.abrahamsson@liu.se

* Corresponding author 
Characteristics of a Logistics-Based Business model 


\title{
CHARACTERISTICS OF A LOGISTICS-BASED BUSINESS MODEL
}

\begin{abstract}
In companies where excellence in logistics is decisive for the outperformance of competitors, and logistics has an outspoken role for the strategy of the firm, there is present what we refer to here as a "logistics-based business model". Based on a multiple case study of three Nordic retail companies, the purpose of this article is to explore the characteristics of such a logisticsbased business model. As such, this research helps to provide structure to logistics-based business models and identifies a way forward for companies for whom logistics and distribution is a major concern for the overall strategy of the firm.
\end{abstract}

Key words Business models, strategic management theory, multiple case study

Paper type Research paper

\section{Introduction}

In recent years the view of logistics has changed from being a tool for cost savings to an enhancer of a company's overall product and service offering (Mentzer et al., 2004), and the impact of logistics and supply chain management (SCM) on overall firm performance has been well established (Tracey et al., 2005). The importance and strategic value of logistics can be seen in several well-known best practice companies such as Dell, Hewlett Packard, H\&M 


\section{Characteristics of a Logistics-Based Business model}

and Inditex, the latter more commonly known through its subsidiary Zara. Excellence in logistics enables the strategic progress of these firms and plays an important role for overall company performance in terms of profitability and growth. Instead of being "productionoriented", "product-oriented" or "market-oriented", these companies are "flow-oriented". In this type of company, where logistics is decisive for the outperformance of competitors and has an outspoken role for the strategy of the firm, there is present what we refer to here as a "logistics-based business model". This business model can be viewed as a "blueprint", or “operationalisation”, of a company’s overall strategy (Osterwalder et al., 2005; Magretta, 2002). Although we recognise from a strategic management perspective that there are other areas of importance for many companies, and that logistics excellence is far from the only way to achieve a sustainable competitive advantage, we argue that there are many floworiented companies that would benefit from improved logistics performance, i.e. a clear and distinct logistics-based business model would be beneficial.

In this article the strategic role of logistics is focused, similar to what the Council of Supply Chain Management Professionals (CSCMP), labels Logistics Management ${ }^{1}$. In line with the functionally broader term of supply chain management (SCM), logistics management typically highlights the importance of including the horizontal dimension, e.g. consideration of the whole supply chain in the logistics work. Theoretically however, there has in general been little effort to include the vertical dimension and build a theory of the role of logistics in the strategy of the firm (Mentzer et al., 2004). To date, most research on logistics strategy has turned its focus towards individual functional operations in isolation (e.g. Autry et al., 2008; McGinnis et al., 2010), and has failed to link logistics with overall company goals such as profitability and growth. To advance logistics research, it may benefit from borrowing theory

\footnotetext{
1 "Logistics management is that part of supply chain management that plans, implements, and controls the efficient, effective forward and reverses flow and storage of goods, services and related information between the point of origin and the point of consumption in order to meet customers' requirements" (www.CSCMP.org)
} 


\section{Characteristics of a Logistics-Based Business model}

from other disciplines (Stock, 1997). Accordingly we believe that research on logistics-based business models offers an increased understanding of logistics' contribution to the overall company performance.

The purpose of this article is to explore the characteristics of a logistics-based business model. Based on the strategic management theories of the resource based view of the firm (RBV) and Industrial Organisation ( $\mathrm{I} / \mathrm{O})$, which can be seen as the theoretical underpinnings of a business model approach, a business model can be divided into three main components: (1) the external environment; (2) the internal factors; and (3) the offering that combines the other two components (Kindström, 2005). Using these three components as an overall structure, this article considers three Nordic retail companies that are flow-oriented, and which each use what we label a logistics-based business model, to explore the logistics related characteristics of each component.

After a discussion on methodology issues, we develop the theoretical foundations for a business model. Thereafter, we explore the logistics related characteristics of our three case companies based on the overall structure of the three generic business model components. Finally analysis and conclusions from our study are drawn.

\section{Methodology}

The application of the "loose" (Arlbjorn \& Halldorsson, 2002) theory basis of business models in a logistics setting is novel and is expected to enrich the logistics field of research, increase the speed of theory development, and illuminate the linkages between logistics and other research disciplines (Stock, 1997). This research can accordingly be described as explorative with a multiple case study as an empirical basis (Yin, 2003; Eisenhardt, 1989). 


\section{Characteristics of a Logistics-Based Business model}

Typically, this kind of study emphasises rich data access in a real-world context in which an interesting phenomena can be observed (Eisenhardt \& Graebner, 2007). Similarly, Eisenhardt (1989) argues that the case study approach is appropriate when one "focuses on understanding the dynamics present in single settings" (p. 534) and when approaching a new topic area.

In order to structure the empirical data in this explorative research, it has been necessary to develop a theoretical ground that consists of strategic management theory. In addition, an extensive literature review on business models has been conducted as a means to get an overview of current research in the area. Apart from considering what a business model actually is, the literature review has been aiming at identification and description of suitable components of a business model. A summary of different authors' content in the three generic components of the external environment, internal factors and offering is shown in Appendix 1.

This research is concerned with logistics-based business models, and the empirical data has been collected with the purpose of informing the generic components identified with a logistics-content. The selected case companies, Bama-Gruppen AS, Clas Ohlson AB and Dustin $\mathrm{AB}$, have the following common characteristics:

- They each display sustained and stable growth and profitability consistently higher than that of the industry average (the average growth rate during the last five years has been $12.5 \%, 14.6 \%$, and $12.6 \%$ for Bama, Clas Ohlson and Dustin respectively) and hence definition-wise have successful business models.

- The growth is coherent, i.e. the expansion of the firm is made in a uniform manner over time, dictated by the chosen business model.

- They have a, by the management, outspoken focus on logistics and its role in the profitability and growth of the firm. 


\section{Characteristics of a Logistics-Based Business model}

- They are known in their respective industry to deliver high value from effective logistics to their customers.

Given these characteristics, the chosen case companies exhibit successful application of a logistics-based business model. They are chosen with a theoretical sampling approach, where richness of data and the possibility to illuminate the content of a logistics based business model is advocated, rather than being representative for a larger population of companies (Eisenhardt \& Graebner, 2007; Flyvbjerg, 2006).

During a period of 2 years (2007-2009) the three selected case companies provided the researchers with considerable access to respondents' time as well as observation opportunities at the companies' facilities and company information such as annual reports, brochures, leaflets, web sites etc. Additionally, semi-structured interviews with respondents predominantly from senior management levels such as operative management groups were conducted, covering areas such as corporate strategy, logistics development and organisational issues. Several interviewees have also been revisited in order to clarify certain pieces of information.

The components identified were applied to the cases through both single case analyses (not presented in this article) and a further simultaneous analysis of all three cases. Overall, the analysis has followed the three steps of open, axial and selective coding as outlined by Ellram (1996). As a first, initial step, the open coding categorised the collected data into the three business model components. As a second step, based on the framework of I/O and RBV and similar to what Yin (2003) labels pattern matching, the data in each component was further structured into tables and compared to the theoretical schools of thought. Finally, the third step in the analysis included a selective coding, in which patterns were sought to explain the 
Characteristics of a Logistics-Based Business model

key phenomenon of interest (Ellram, 1996). These patterns, or "stories", can be seen in the analysis chapter of this article.

\section{Theoretical framework}

\subsection{Theoretical underpinnings of business models}

Inherent in the business model concept are two opposing schools of thought in strategic management theory: RBV and I/O (Afuah, 2004; Amit \& Zott, 2001). This duality is characteristic for business model literature (e.g. Hedman and Kalling, 2003; Afuah, 2004; Kindström, 2005), taking a more holistic view of strategy and operations and thus acknowledging that there may be several possible theoretical explanations behind why some firms succeed and others do not.

The I/O perspective (Porter, 1980; 1985) is occupied with the need for a prosperous market position of a company, arguing that it is this position that gives a company a sustainable competitive advantage and, as a result of this, an above normal profitability. In essence, the I/O perspective suggests that a company should (1) choose an attractive industry to operate within, considering the five forces: potential entrants, suppliers, substitutes, buyers, and industry competitors and (2) choose one of three possible generic strategies, for instance, decide whether it should be a cost leader, differentiator, or focused firm relative to other players in that industry. Correct strategic choices concerning these two questions will lead to a sustainable competitive advantage (Grant, 1991).

Contrary to the I/O perspective, RBV assumes that (1) companies have access to different resources leading to competitive advantage and that the factor market for these resources is heterogenic, and (2) that the resources may not be highly mobile, i.e. are difficult to imitate 


\section{Characteristics of a Logistics-Based Business model}

(Barney, 1991, Barney \& Clark, 2007). The basic cornerstone for competitive advantage is hence to have access to superior resources, also named capabilities. In order to avoid imitation and competitive erosion, these capabilities tend to be complex (Olavarrieta \& Ellinger, 1997), cross-functional (Day, 1994, Grant, 1991, Stalk et al., 1992) and tacit (Grant, 1991).

To judge what capabilities lead to sustainable competitive advantage, the empirical indicators developed by Barney (1991) and further developed by Barney \& Clark (2007) can be applied. In essence, this framework implies that capabilities that provide the company with a sustainable competitive advantage must be valuable, rare, and difficult to imitate (imperfectly imitable). Value of the actual capability is understood to be created both in an effectiveness, as well as an efficiency dimension of company performance, searching for decreased costs as well as improved services. The rare criterion means that only relatively few existent and potential competitors must possess the capability. Finally, the imperfectly imitable criterion means that the capability at hand must either (1) have unique historical conditions, (2) be causal ambiguous, or (3) be a socially complex resource (Barney, 1991; Barney \& Clark, 2007).

From a resource-based perspective, building on Barney's (1991) framework on what constitutes a distinctive capability, it can be argued that logistics and SCM practices can be seen as distinctive capabilities that are valuable, rare and difficult to imitate, which in turn gives the company a sustainable competitive advantage (Ketchen and Giunipero, 2004; Barney \& Clark, 2007; Olavarrieta \& Ellinger, 1997). Examples of such capabilities are customer focused capabilities, supply management capabilities, integration capabilities, measurement capabilities, and information exchange capabilities (Esper et al., 2007). For companies with a logistics-based business model these capabilities hence becomes essential to manage and possess. 


\subsection{What is a business model?}

A business model is to a large extent the operationalisation of a business strategy and hence a road map for managers to follow (Magretta, 2002). Tikkanen et al. (2005) point out that the business model concept refers to the logic and functioning of the firm, and is subsequently a tool to use in describing the interplay between operations and strategy and hence, in our case, connect the activities and processes of logistics with strategy. However, in academic research there has been confusion of what a business model is (Osterwalder et al. (2005); business models have been described as archetypes, configurations, schools, gestalts and in some cases even as strategies and business ideas (Kindström, 2005). Most use of the term and concept of business models in research of today remains to be found in the interface between management and IT, e.g. in E-business (Magretta, 2002), whereas the application of a business model approach in a logistics context is novel. Osterwalder et al. (2005) defines a business model as:

"a conceptual tool that contains a set of elements and their relationships and allows expressing the business logic of a specific firm. It is a description of the value a company offers to one or several segments of customers and of the architecture of the firm and its network of partners for creating, marketing, and delivering this value and relationship capital, to generate profitable and sustainable revenue streams”. (Osterwalder et al., 2005, p. 10)

Business models are mainly occupied with explaining how companies are supposed to create and commercialise value (Osterwalder et al., 2005; Amit \& Zott, 2001; Chesbrough, 2007). Afuah (2004) states that a business model "is the set of which activities a firm performs, how it performs them, and when it performs them as it uses its resources to perform activities, given its industry, to create superior customer value (low-cost or differentiated products) and 


\section{Characteristics of a Logistics-Based Business model}

put itself in a position to appropriate the value" (Afuah, 2004, p. 9). This possibility of a business model to aid in linking the activities of the firm with the strategy means that the business model can be used as a tool to describe and analyse the role of those activities, and of those processes in which the activities are pursued, in the strategy of the firm. In summary, a business model is a distinctive description of how a company structures its operations and resources, acts on the market and makes profit in its daily business.

A business model consists of a set of components and different alternatives for such constellations have been put forward over the years (Osterwalder et al., 2005; Amit \& Zott, 2001; Kindström, 2005). In its simplest form, Kindström (2005) describes a generic business model as having three components; the external environment, the internal factors and the offering in between that connects the other two. Appendix 1 shows a summary of different authors' components and how they are related to the three components used in this research. As can be seen in the Appendix, the external environment incorporates issues such as how the company positions itself on the market and how it handles external competitive forces, typically including customers and/or competitors (e.g. Hedman \& Kalling, 2003). As such, the component has its roots in the Porterian I/O perspective. Opposed to this component, the internal factors stem theoretically from RBV, and typically incorporate activities, resources, and the internally managed operative platform. From an internal viewpoint, two main questions emerge: (1) how is potential shareholder- and customer- value created in the company and/or supply chain, and (2) how are transactions enabled that can realise the potential value (Amit \& Zott, 2001). Finally, the offering component incorporates matters of the exchange of products and services with customers and hence relates the other two components to each other. 


\section{Analysis}

The characteristics of a logistics-based business model are explored through the practices of three Nordic retail companies: Bama Gruppen AS, Clas Ohlson Group AB, and Dustin Group AB.

Bama Gruppen AS (Bama) is a Norwegian distributor of fruit, vegetables and flowers operating on the Norwegian market. Bama has grown with sustained profitability for many years and has a turnover of Euro 790 million (2008/2009). The main owner is Norgesgruppen, which controls almost $40 \%$ of the total sales of fruit and vegetables on the Norwegian market via a number of food chains. There are two other large owners; the old owner family Nergaard, and Rema 1000, who is a competitor of Norgesgruppen. Despite the competition between the owners, Bama has been working successfully together with both companies and developed their customers' sales and logistics strategies for fruits and vegetables.

Clas Ohlson Group AB (Clas Ohlson) is a Swedish retailer of do-it-yourself and household products. It has a history as a mail-order company, but has successfully expanded its business with stores, that today represent $98 \%$ of the sales. Clas Ohlson operates 121 stores (June 2010) in Sweden, Norway, Finland and the UK, with approximately 3.100 employees and Euro 490 million turnover (Annual report 2008/2009). The company is listed on the Stockholm stock exchange market.

Dustin Group AB (Dustin) is an Internet-based retailer of IT products operating in the Swedish and Danish markets and had a yearly turnover of about Euro 400 million in 2008/2009. The product portfolio extends to around 65,000 articles and today's concern has about 350 employees. The company was founded in 1984 and was managed as a family business until 2005 when $80 \%$ of the shares were sold to a private equity company. Dustin operates on the business-to-business market as well as on the business-to-consumer market 


\section{Characteristics of a Logistics-Based Business model}

with two different websites, offering a broad assortment and several value-adding services such as financial solutions, configuration services, etc. All products are purchased via multinational distributors and taken to Dustin's central warehouse in Stockholm. From here the products are delivered to the end customers 1-2 days after the order is received and processed.

\subsection{External environment}

\section{Multiple generic strategies}

A company's position on the market can be described in terms of Porter's (1985) three generic strategies. Porter's claim of being "stuck in the middle" if a company does not stick to one generic strategy has, however, been criticised, and logistics scholars have, for a long time, discarded Porter's claim, arguing that superior logistics may simultaneously be the foundation and enabler for a market position based on cost leadership and service differentiation (Christopher, 2005; Persson, 1991). According to these authors the ultimate mission for logistics - and hence also for a logistics-based business model - is to perform well in more than one generic strategy dimension. To understand and incorporate consequences for costs as well as services in the same decision model is key for logistics superiority.

The case companies provide excellent support for this statement; despite differences in their types of operation, product and market, they resemble each other at an overarching level in that they have successfully positioned themselves in such a way that they can offer customers a unique combination of low cost and differentiation. For Bama this double market position is clearly mirrored in the demands from its two largest customers (and owners), Norgesgruppen and REMA 1000, as they have different profiles on the market. Whereas Norgesgruppen requires more service and deliveries to smaller stores, REMA 1000 competes more on price 


\section{Characteristics of a Logistics-Based Business model}

and therefore require their supplier, Bama, to offer cost efficient, lean supply chain solutions. To fulfil these two market requirements Bama, has changed its organisational structure to match the way the larger customers are organised. Bama has been able to align its operations and strategy to its customers' specific requirements through two separate customer divisions. At the same time, the supplier side of Bama is highly centralised, so that customer requirements for service and availability can be combined with search for economies of scale, particularly in transportations.

For Clas Ohlson, the cost leadership strategy can be identified in what is labelled "good value for money products", where a combination of own brands and market brands provide their customers with a full range of products in different price segments. Clas Ohlson differentiate themselves from competitors through their prime locations in the very centre of cities. In addition, in comparison to other low cost alternatives, Clas Ohlson has a strong service profile; customers are offered full transparency between different stores and Internet sales, and despite the cost disadvantages, the full product range is offered in all stores.

Dustin operates in a rapidly changing market characterised by low margins and short product lifecycles. To manage competition, the business model focuses on speed, enabling high product availability and short lead times to customers. By linking their four largest distributors to their own IT-system and having a centralised product range and processes in the central warehouse, Dustin has an inventory turnover of as much as 40 times per year. This set up supports Dustin's business model and allows them to compete through a combination of competitive pricing, large product range and high availability.

\section{Utilisation of the entire supply chain}

A business model's main reference point is centred to a particular company. However, the business model as such has a wider scope and can include other stakeholders (Amit \& Zott, 


\section{Characteristics of a Logistics-Based Business model}

2001), which is evident in the case companies. The case companies have all taken a leading position in their supply chain, similar to a channel captain's role (Cooper \& Ellram, 1993), where the domain of control for the companies could be argued to span not only the immediate supply chain parties, but also includes other partners upstream in the supply chain. Activities and organisation of the entire supply chain are considered and company borders as well as functional borders between supply, marketing and sales are blurring. This integration of the physical flow is illustrated in Figure 1.

\section{Insert Figure 1 here}

For Bama, this means continuous updating and development of their supplier base. Since fruit and vegetables are typically dependent on weather conditions, alternative suppliers in different regions of the world are necessary. In case of poor growth in one region, Bama must be able to rapidly change to another supplier. At the same time though, Bama makes efforts to integrate the supply chain by educating the suppliers in, for instance, customer requirements and quality standards of the Norwegian market.

Clas Ohlson utilises supply chain opportunities for cost advantage as well as service improvement. An important part of this work is contacts made with manufacturers upstream in the supply chain although all products are procured via agents or trading houses. This collaboration with these second tiers is covering topics such as long-term forecasts, new product development etc.

Similar to the other two case companies, Dustin utilises the entire supply chain for their purposes. Dustin maintains a close collaborative dialogue with the manufacturers as regards sales forecasts although all products are procured via distributors. It is important for Dustin to 


\section{Characteristics of a Logistics-Based Business model}

utilise the complete range of relationships, from collaboration to short term transactions with other supply chain members. For instance, as regards the relations to their 1:st tier up-stream distributors, Dustin pursues active haggling with their $1^{\text {st }}$ tier distributors in order to achieve short-term profitability gains whilst at the same time Dustin sustains long-term strategic relationships with the suppliers (second tier providers).

\section{A combination of lean and agile strategies}

In terms of lean and agile logistics strategies (e.g. Christopher, 2005), the extended domain of control also enables the case companies to better design the entire supply chain. In all three cases different forms of hybrid logistics strategies, with both lean and agile components for either different parts of the flow or for different dimensions of the flow, are being employed. The cases show that hybrid strategies, as described by Christopher (2000), employed by a firm pursuing a logistics-based business model may not only be lean or agile for different markets or for different parts of the supply chain respectively, but also combine a lean flowdimension with an agile assortment-dimension. For example, Dustin's strategy is not split between different parts of the Dustin flow; see part 1 of Figure 2; neither is it split for

different markets or different product groups as in part 2 of the figure. Instead, Dustin manages to be agile in terms of assortment and lean in terms of activities, see part 3 of Figure 2. Also in the Bama and Clas Ohlson cases the agile characteristics were found in the assortment whereas lean characteristics were found in the processes.

Insert Figure 2 here 


\section{Characteristics of a Logistics-Based Business model}

A common denominator behind the lean processes handling a varying assortment (part 3 of Figure 2) is the set of standardized procedures in, for example, the order-to-delivery processes, aimed at contributing to the efficiency of the operations while simultaneously offering a high degree of flexibility. This can be seen in Bama's preparedness towards sudden weather-changes affecting the regions from which fruit can be sourced; in Dustin's ability to adapt to changing demand quickly by access to the distributors' stock levels, and by Clas Ohlson's ability to ramp up sales and deliveries to new stores in new regions.

The logistics content in the external environment dimension can be summarised as in Table 1:

Insert Table 1 here

\subsection{Internal factors}

\section{Well organised, simple operational logistics processes}

Starting with the logistics activities in the companies, the processes applied, in for example, the central warehouses are thought-through and in most instances very simple. Technical equipment is used when improving efficiency but is not always considered necessary. As an example, in the Bama distribution centres, order points for the different products are determined by visual inspection since fruit and vegetables are, to a large extent, not sold in discrete packages; technology at Bama is continuously evaluated but not always found worth large-scaled investment efforts. As a contrast, in the Clas Ohlson warehouse, state of the art computer controlled warehousing systems are used. In the Dustin warehouse, all picking is done manually, but the physical flow of goods is closely integrated with the IT-system 
Characteristics of a Logistics-Based Business model

ensuring control of the processes. For example, a photo is made of each open package before dispatch allowing for backtracking in cases of theft etc.

\section{Centralisation of logistics design, planning and control}

Organisationally, all logistics activities and processes in the case companies are centrally decided, managed and controlled, and logistics is part of the senior management's agenda. However, the cases represent different opportunities when it comes to how centralised the physical flow of goods is. Bama has kept the overall responsibility for the logistics organisation and planning centrally, executed through the purchasing organisation. However, the physical flow of goods is decentralised so that the two main customers, Norgesgruppen and Rema 1000 get different deliveries. The physical flow of goods to the customers is also separated so that for instance in a distribution centre two separate units are handled. The opposite situation can be found at Clas Ohlson, where the physical flow of goods is completely centralised. All goods from all suppliers are taken to the central warehouse in Sweden, and are then further distributed to the stores in the Nordic countries and in the UK. The opening of a new store is managed in a standardised way in the warehouse, where it only generates an extra delivery address at the outbound area. All stores are stockless and are replenished 5 times a week. Similarly to Clas Ohlson, Dustin also has a centralised physical flow of goods; the warehouse is operated and managed in the same, highly standardised way for customers in different markets and customer segments. In the IT system employees as well as customers operate - but the system is linked to two different websites that are adjusted to the targeted market segments. 


\section{Characteristics of a Logistics-Based Business model}

\section{IT and logistics operations constitutes a distinctive capability}

From a resource based perspective, logistics activities are an essential factor for the strategic and competitive performance of the companies. As retailers, no particular resources such as patents or unique products form the basis for the competitive advantage. Instead, the competitive strength is grounded in how they manage their flow of goods throughout the supply chain, the logistics operations and the IT system, which has a long history of joint internal development in each of the companies. Considering Barney \& Clark's (2007) criteria of what constitutes a sustainable competitive advantage, i.e. value, rareness and imperfectly imitable, it can be argued that the physical resources such as the central warehouses of the case companies, the distribution structures and the technical warehousing equipment, etc. are investments that improve the efficiency and effectiveness of the operations and are as a result valuable. Perhaps they may also, to some extent, be considered as rare, as they are the result of in-house development of IT systems. However these resources are, on their own, not to be considered as imperfectly imitable, since similar, unique IT systems can be developed by competitors.

Thus, the IT systems or the logistics processes are on their own not a source for a sustainable competitive advantage following Barney \& Clark's requirements. Instead, we argue, it is the control of these resources and how they are combined, that constitute a company's sustainable competitive advantage. For instance, this control is seen in the usage of KPIs in the companies. Over the years it has been the physical logistics processes that have dictated the design of the IT-systems and not the other way around. The studied firms rarely need to make trade-offs as regards KPI's. The control over the IT-systems and their adaptation to the processes conducted in the operations make the extraction of sought KPI's possible. Indeed, in the studied cases, one can measure what one wishes to measure. 


\section{Characteristics of a Logistics-Based Business model}

A proper control enables efficient utilisation of IT systems and logistics processes and is hence valuable for the companies in terms of cost efficiency as well as effectiveness. Apart from simple, off-the-shelf logistics services, the companies are also able to offer more comprehensive services in the form of bundling of products (Dustin), financial solutions (Dustin), configuration services (Dustin, Bama), different market channels with full transparency (Clas Ohlson, Bama), and updated and rapidly renewed assortment (Clas Ohlson, Dustin, Bama). These services all translate into higher value. The control is also rare; most of the competition is unable to keep the cost of operations as low as the studied firms manage to. The in-house IT systems have, for many years, been adapted and refined to suit the requirements of the logistics operations. Indeed, as a capability, the close control of the operations has not been created overnight but has evolved over time through constantly attempting to improve the operations and the IT-systems. This makes it difficult to imitate due to the history dependent inimitability. In addition, the individual relationships between IT and logistics, and the related human skills among employees, make the capability socially complex (Barney \& Clark, 2007).

The logistics content in the internal dimension can be summarised as in Table 2:

Insert Table 2 here

\subsection{Offering}

\section{Flexibility in logistics supports a unique set of offerings}

The offering component, linking the environment (market) to the internal factors (Kindström, 2005), consists in the case companies of highly commoditised products, bundled with high 


\section{Characteristics of a Logistics-Based Business model}

degree of flexibility in terms of customer differentiation and the ability to rapidly change assortment.

All three case companies offer a broad assortment of commodities in their respective sector; Clas Ohlson offers around 13,000 good value for money products for house and home; Dustin about 65,000 IT products, and Bama a wide range of fruit, vegetables and flowers. As such, the products themselves are not unique and all three companies operate in typically low profit margin sectors. Instead, what makes the offering of the three companies competitive - and hence decisive for the competitive strength of the companies - is the flexibility of the offering, which enables high customer service to different customers in different sales channels, from high availability of a large assortment. In this offering, logistics plays a crucial role. For instance, Bama has, as was described above, a central supply function, but has split the distribution operation into two different distribution networks and customer organisations for its two largest customers Norgesguppen and Rema 1000. Thus economies of scale on the inbound side can be combined with customised solutions on the outbound side, where different customers are offered their products in different ways in the form of deliveries, packages and branding, etc. Bama also displays high flexibility when it comes to allocation of products. To shorten the total order lead time, and based on their own IT system, Bama purchases fruit around the world on speculation, allocating and routing the product to specific customers during transportation.

Clas Ohlson has a central supply function and a central warehouse that supports offerings to customers in the Clas Ohlson stores, mail-order and Internet customers. The offerings to all customer categories are managed centrally from the central warehouse. Finally Dustin offers a very broad range of IT peripherals, bundled with services such as configurations, to private consumers as well as company customers. Despite the different customer segments, managed 
Characteristics of a Logistics-Based Business model

through different homepages and sales conditions, Dustin is able to change up to 100 products every day of their total assortment (due to short life cycles and updates of products).

\section{One single operative logistics platform}

An interesting common denominator in all three cases is that they are able to support multiple offerings with one single operative logistics platform (Abrahamsson et al., 2003). Bama, despite several separate physical flows of goods, is able to utilise the same warehouses, equipment and personnel for the different flows, and thus balance their resources. Clas Ohlson, thanks to their centralised warehouse in combination with standardisation of bar codes and picking routines etc., also has one single platform for their different offerings to different types of customers (stores, Internet and mail customers). In a similar way, Dustin uses its IT system and central warehouse as a platform for both the business-to-business and business-to-consumer market. Thus, behind the scenes, there is one IT-system with one single database and one single physical warehouse, and for the warehouse personnel it is only the logo on the picking lists that conveys via which portal the customer has placed the order.

The logistics content in the offering dimension can be summarised as in Table 3:

Insert Table 3 here

\section{Discussion}

The discussion on business models in logistics literature has been very sparse and as a means to further increase the understanding of the role of logistics, we have in the previous chapter, outlined the logistics characteristics of the three generic business model components of 


\section{Characteristics of a Logistics-Based Business model}

external environment, internal factors and offering. In summary we have found following pattern for a logistics-based business model:

- A logistics-based business model incorporates a multiple set of generic position strategies

- The entire supply chain is exploited to enhance cost and service benefits, i.e. position in the supply chain is important

- Hybrid strategies are applied, i.e. a combination of lean and agile logistics strategies

- Logistics operations are simple and standardised, but well organised and thoughtthrough

- Logistics design, planning and control are managed centrally

- Control of the combination of IT and logistics is a distinctive capability

- Flexibility in logistics operations supports a unique set of offerings

- A logistics based business model includes one single logistics platform

As such, the study can be summarised into three overall findings.

First, the cases show that the characteristics of a logistics-based business model go beyond traditional company borders and, similarly to supply chain management, incorporate not only internal logistics activities, but include activities along the entire supply chain. A logisticsbased business model hence requires a supply chain approach to logistics, including internal as well as external coordination of the flow of goods. Coordination is in the case companies, achieved not only with the immediate supply chain parties but also with parties further up- or downstream. The type of relationship sought may, however, differ and although there are resources and capabilities present that enable a high level of logistics advancement (i.e. close collaboration), following the traditional logistics strategy classifications, this is not always 


\section{Characteristics of a Logistics-Based Business model}

sought by the firm. In addition, close strategic cooperation with 2 nd tier supply chain parties can be reached at the same time as the relationship with the 1st tier has arm's length characteristics. As a result, gains in local operational efficiency can at times be abandoned when it is believed that the local efficiency could reduce the overall (company wide) effectiveness and added value to the customer.

Second, the expanded domain of control clearly emphasises the match and/or integration between logistics activities and market aspects. This has previously been discussed in terms of the need for a strategic fit between logistics activities and the market (Stonebraker \& Liao, 2006; Daugherty et al., 2009). This wider functional scope enables new approaches when it comes to lean and agile strategies in the supply chain (Christopher, 2000; 2005), which is an important cornerstone for logistics-based business models. Except for designing lean and agile parts of the supply chain, or granting certain markets or products into a lean or agile strategy, a third hybrid strategy has been observed among the case companies. This strategy includes the ability to handle a varying flow of goods as regards volume and assortment, while at the same time pursuing lean processes. One example of this is Dustin's ability to be highly standardised in warehouse processes, i.e. lean, and at the same time be agile towards customer demands in terms of combining these standardised processes into a different set of offerings. In terms of Towill \& Christopher (2002), this indicates that the combination of being lean and agile at same time and in the same space, which they argue is invalid, could be valid after all.

Third, except for a match between logistics and the market, this study shows that it is necessary to integrate the rather simple, traditional logistics activities with other company functions, in particular the IT function but also marketing and sales. Interestingly, the case companies all have a long history of very intimate relationships between logistics and IT, often managed by the same person, and the IT systems have been developed in-house over the 


\section{Characteristics of a Logistics-Based Business model}

years with the primary goal of supporting the physical flow of goods. The control of the logistics resources, assured by a proper IT system, has been identified as a distinctive capability in the case companies. When discussing resources in logistics, physical resources often come first; in this research, logistics resources were identified in both the operations conducted within the physical logistics processes in the firm, e.g. the order-to-delivery processes in the central warehouses and the IT-systems used to support and drive those processes. Nevertheless, the operations as well as the IT systems are seen as quite simple 'bread and butter' resources. What is seen as essential, however, is the control over these resources since this is what constitutes a distinctive capability in firms pursuing logisticsbased competition.

\section{Implications}

This research has taken a business model approach as a means to structure and explore the content of logistics-based business models and, ultimately, contribute to the understanding of the role of logistics in the strategy of the firm. This approach benefits above all from a new type of analytical framework where logistics are put into a larger setting and are discussed together with other business aspects. Among other market issues, as well as functions such as IT, are important fields that are discussed and combined with traditional logistics issues. As such, the findings from the study encourage further cross-disciplinary studies, where logistics aspects are combined and considered together with other areas such as marketing.

In the introduction it was argued that companies have a logistics-based business model if excellence in logistics is decisive for the outperformance of competitors, and where logistics plays an important role for the strategy of the firm. This means that a logistics based business 


\section{Characteristics of a Logistics-Based Business model}

model is primarily for flow-oriented companies, where the flow of goods represents a large part of total cost and where availability is important for creation of customer value. Typically, retail companies in the industries of Do-It-Yourself, Food, and IT products (represented in this study) offering standardised products in highly competitive markets, are likely to compete with a logistics-based business model. For companies that are product-, production-, or market oriented, logistics will very likely not have such an impact on the business model.

It is important to note that the characteristics outlined in this article are all to be considered best practice behaviour - there is, however, no evidence that all characteristics are required for a successful company. Rather, the identified characteristics should be seen as a palette of different opportunities for a company. This also means that the characteristics are not a complete list of opportunities - there might be other possibilities that can constitute a logistics-based business model. Further research is needed in this area to confirm and develop more rigorous characteristics in each business model component.

From a managerial viewpoint, a logistics-based business model requires a top management team that keeps logistics development high on the strategic agenda. This article illuminates a number of key managerial challenges, including for instance, design of supply chain-wide logistics processes and a more extensive focus on coordination activities with other supply chain members, including relationship management activities. As such, the exploration of the characteristics can be seen as helpful for managers wishing to prioritise their logistics development. 


\section{References}

Abrahamsson, M., N. Aldin and F. Stahre (2003). Logistics platforms for improved strategic flexibility. International Journal of Logistics: Research and Applications, 6 (3), 85-106.

Amit, R. and Zott, C. (2001). Value creation in e-business. Strategic Management Journal, 22, 493-520.

Afuah, A. (2004). Business Models - A Strategic Management Approach. McGraw-Hill Irwin.

Arlbjörn, J. S. and Halldorsson, A. (2002). Logistics knowledge creation: reflections on content, context and processes. International Journal of Physical Distribution \& Logistics Management, 32(1), 22-40.

Autry, C., Zacharia, Z., and Lamb, C. (2008). A Logistics Strategy Taxonomy. Journal of Business Logistics, 29(2), 27-51.

Barney, J. (1991). Firm Resources and Sustained Competitive Advantage. Journal of Management, 17(1), 99-120.

Barney, J. and D. Clark (2007). Resource-Based Theory: Creating and Sustaining Competitive Advantage. Oxford, Oxford University Press.

Chesbrough, H. and Rosenbloom, R. S. (2002). The role of the business model in capturing value from innovation: evidence from Xerox's Corporation's technology spin-offs companies. Industrial and Corporate Change, 11(3), 529-555.

Chesbrough, H. (2007). Business model innovation: it's not just about technology anymore. Strategy \& Leadership, 35(6), 12-17.

Christopher, M. (2000). The agile supply chain: Competing on volatile markets. Industrial Marketing Management, 29(1), 37-44.

Christopher, M. (2005). Logistics and Supply Chain Management - Creating Value-Adding Networks. Harlow, Pearson Education Limited.

Cooper, M. and Ellram, L. (1993). Characteristics of Supply Chain Management and the Implications for Purchasing and Logistics Strategy. The International Journal of Logistics Management, 4(2), 13-24.

CSCMP, http://www.cscmp.org, the official website of the Council of Supply Chain Management Professionals, accessed 2010-08-20.

Daugherty, P., Chen, H. Mattioda, D. and Grawe, S. (2009). Marketing/Logistics relationships: Influence on capabilities and performance. Journal of Business Logistics, 30(1), $1-18$.

Day, G. S. (1994). The capabilities of market-driven organizations. Journal of Marketing 58(4), 37-52.

Eisenhardt, K. (1989). Building Theories from Case Study Research. Academy of Management Review, 14(4), 532-550. 
Eisenhardt, K. and Graebner, M.E. (2007). Theory building from cases: opportunities and challenges. Academy of Management Journal, 50(1), 25-32.

Ellram. L. (1996). The use of the case study method in logistics research. Journal of Business Logistics, 17(2), 93-138.

Esper, T., B. Fugate, and B. Davis-Sramek (2007). Logistics Learning Capability: Sustaining the Competitive Advantage through Logistics Leverage. Journal of Business Logistics, 28(2), 57-81.

Flyvbjerg, B. (2006). Five misunderstandings about case study research. Qualitative Inquiry, 12(2), 219-245.

Grant, R. (1991). The Resource-Based Theory of Competitive Advantage: Implications for Strategy Formulation. California Management Review, 33(3), 114-135.

Hedman, J. and Kalling, T. (2003). The business model concept: theoretical underpinnings and empirical illustrations. European Journal of Information Systems, 12, 49-59.

Ketchen, D. J. and Giunipero, L. C. (2004). The intersection of strategic management and supply chain management. Industrial Marketing Management, 33, 51-56.

Kindström, D. (2005), The Integration of E-business into Mature and Established Companies. Doctoral dissertation, Linköping, Linköpings universitet.

Mahadevan, B. (2000). Business models for Internet-based e-commerce. California Management Review, 42(4), 55-69.

Magretta, J. (2002). Why Business Models Matter. Harvard Business Review, 80(5), 86-92.

McGinnis, M., Kohn, J., and Spillan, J. (2010). A longitudinal study of logistics strategy: 1990-2008. Journal of Business Logistics, 31(1), 217-235.

Mentzer, J. T., Soonhong, M. and Bobbit, L. M. (2004). Toward a unified theory of logistics. International Journal of Physical Distribution \& Logistics Management, 34(8), 606-627.

Miller, D. and Whitney, J. (1999). Beyond strategy: Configuration as a pillar of competitive advantage. Business Horizons, 42(3), 5-17.

Normann, R. (2001). Reframing Business - When the Map Changes the Landscape. Chichester, John Wiley \& Sons Ltd.

Olavarrieta, S. and Ellinger, A. E. (1997). Resource-based theory and strategic logistics research. International Journal of Physical Distribution \& Logistics Management, 27(9/10), 559-587.

Osterwalder, A., Pigneur, Y. and Tucci, C. (2005). Clarifying business models: origins, present, and future of the concept. Communications of the association for information systems, 16, 1-25.

Persson, G. (1991). Achieving Competitiveness Through Logistics. The International Journal of Logistics Management, 2(1), 1-11. 
Porter, M. E. (1980). Competitive strategy: techniques for analyzing industries and competitors. New York, Free Press.

Porter, M. E. (1985). Competitive advantage: creating and sustaining superior performance. New York, Free Press.

Porter, M. E. (1991). Towards a dynamic theory of strategy. Strategic Management Journal, 12(9), 95-117.

Sandberg, E. and M. Abrahamsson (2010). The role of top management in supply chain management practices. International journal of Retail \& Distribution management, 38(1), 5769.

Stalk, G, Evans, P. and Shulman, L. (1992). Competing on Capabilities: The New Rules of Corporate Strategy. Harvard Business Review, 70(2), 57-69.

Stock, J. R., (1997). Applying theories from other disciplines to logistics. International Journal of Physical Distribution \& Logistics Management, 27(9/10), 515-539.

Stonebraker, P. and Liao, J. (2006). Supply chain integration: Exploring product and environmental contingencies. Supply Chain Management: An International Journal, 11(1), 3443.

Tikkanen, H., Lamberg, J.-A., Parvinen P., and Kallunki, J-K. (2005). Managerial cognition, action and the business model of the firm. Management Decision, 43(6), 789-809.

Towill, D. and Christopher, M. (2002). The Supply Chain Strategy Conundrum: To be Lean Or Agile or To be Lean And Agile? International Journal of Logistics: Research and Applications, 5(3), 299-309.

Tracey, M., Jeen-Su, L. and Vonderembse, M.A., (2005). The impact of supply-chain management capabilities on business performance. Supply Chain Management: An International Journal, 10, 179-191.

Yin, R. K. (2003), Case study research: design and methods. second edition, Sage Publication 
Appendix 1: Content in the three business model components - a summary of different authors' view

\begin{tabular}{|c|c|c|c|c|c|c|c|c|c|c|}
\hline & Afuah (2004) & Amit and Zott (2001) & \begin{tabular}{|l|} 
Chesbrough and \\
Rosenbloom (2002)
\end{tabular} & $\begin{array}{l}\text { Hedman and Kalling } \\
(2003)^{\prime}\end{array}$ & $\begin{array}{l}\text { Kindström (2005), } \\
\text { Normann (2001) }\end{array}$ & Magretta (2002) & Mahadevan (2000) & $\begin{array}{l}\text { Miller and Whitney } \\
(1999)^{2}\end{array}$ & Porter (1991) & Tikkanen et al. (2005) \\
\hline \multirow[t]{2}{*}{$\begin{array}{l}\text { External } \\
\text { environment }\end{array}$} & $\begin{array}{l}\text { Positions, (The activities } \\
\text { that the firm pursues must } \\
\text { be consistent wivth the } \\
\text { position of the firm on the } \\
\text { market) }\end{array}$ & $\begin{array}{l}\text { Transaction structure (The } \\
\text { parties that participate in } \\
\text { the exchange and the way } \\
\text { in which these parties are } \\
\text { linked, and the order in } \\
\text { which exchanges take } \\
\text { place.) }\end{array}$ & $\begin{array}{l}\text { Formulating the } \\
\text { competitive strategy }\end{array}$ & Customers & Market positions & 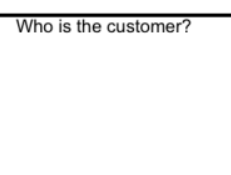 & & 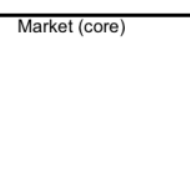 & $\begin{array}{l}\text { Industry structure (five } \\
\text { forces) }\end{array}$ & 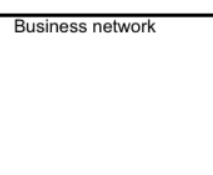 \\
\hline & $\begin{array}{l}\text { Industry factors (The } \\
\text { activities pursued may } \\
\text { influence the competitive } \\
\text { forces and vice versa.) }\end{array}$ & & $\begin{array}{l}\text { Identification of market } \\
\text { segment } \\
\text { Describing the position of } \\
\text { the firm witin the value } \\
\text { network }\end{array}$ & Competitors & & $\begin{array}{l}\text { How do we make money } \\
\text { in this business? }\end{array}$ & & Mission (core) & Position & Strategy and structure \\
\hline Offering & & $\begin{array}{l}\text { Transaction content (The } \\
\text { goods or information that } \\
\text { are being exchanged, and } \\
\text { the resources and } \\
\text { capabilities that are } \\
\text { required to enable the } \\
\text { exchange.) }\end{array}$ & $\begin{array}{l}\text { Articulation of value } \\
\text { proposition }\end{array}$ & Offering & Offering & $\begin{array}{l}\text { What does the customer } \\
\text { value? }\end{array}$ & Value stream & & & \\
\hline \multirow[t]{3}{*}{ Internal factors } & Activities & $\begin{array}{l}\text { Transaction content (The } \\
\text { goods or information that } \\
\text { are being exchanged, and } \\
\text { the resources and } \\
\text { capabilities that are } \\
\text { required to enable the } \\
\text { exchange.) }\end{array}$ & $\begin{array}{l}\text { Defining the structure of } \\
\text { the value chain within the } \\
\text { f firm }\end{array}$ & Activities and organisati & Operative platforms & $\begin{array}{l}\text { What is the underlying } \\
\text { economic logic that } \\
\text { explains how we can } \\
\text { deliver value to customers } \\
\text { at an appropriate cost? }\end{array}$ & Value stream & Means (core) & 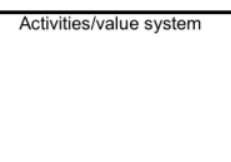 & 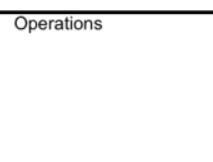 \\
\hline & $\begin{array}{l}\text { Resources (The } \\
\text { actitivities should leverage } \\
\text { the firm's resources.) }\end{array}$ & $\begin{array}{l}\text { Transaction structure (The } \\
\text { parties that participate in } \\
\text { the exchange and the way } \\
\text { in which these parties are } \\
\text { linked, and the order in } \\
\text { which exchanges take } \\
\text { place.) }\end{array}$ & $\begin{array}{l}\text { Estimating the cost } \\
\text { structure and profit } \\
\text { potential }\end{array}$ & $\begin{array}{l}\text { Supply of factor and } \\
\text { production inputs }\end{array}$ & & & Logistics stream & & $\begin{array}{l}\text { Drivers (Structural } \\
\text { determinants of } \\
\text { differences in the cost or } \\
\text { buyer value of activities or } \\
\text { groups of activities) }\end{array}$ & Finance and accounting \\
\hline & $\begin{array}{l}\text { Costs (Since there is a } \\
\text { cost associated with } \\
\text { performing an activity.) }\end{array}$ & $\begin{array}{l}\text { Transaction governance } \\
\text { (The ways in which flows } \\
\text { (of information, resources, } \\
\text { and goods are controlled } \\
\text { by the relevant parties. } \\
\text { also handles the legal } \\
\text { form of organisation and } \\
\text { the incentives for the } \\
\text { participantst in } \\
\text { transactions.) }\end{array}$ & & Resources & & & Revenue stream & & & \\
\hline & $\begin{array}{l}\text { 1. Hedman and Kalling } \\
\text { also include a longitudinal } \\
\text { process-component }\end{array}$ & & & & & & & & & \\
\hline
\end{tabular}


Characteristics of a Logistics-Based Business model

Figures and Tables to be inserted in the text

\begin{tabular}{|l|l|l|l|}
\hline Suppliers & Supply Marketing and Sales \\
& Logistics & \\
& & \\
& & \\
\end{tabular}

Figure 1: Integrated organisational structure
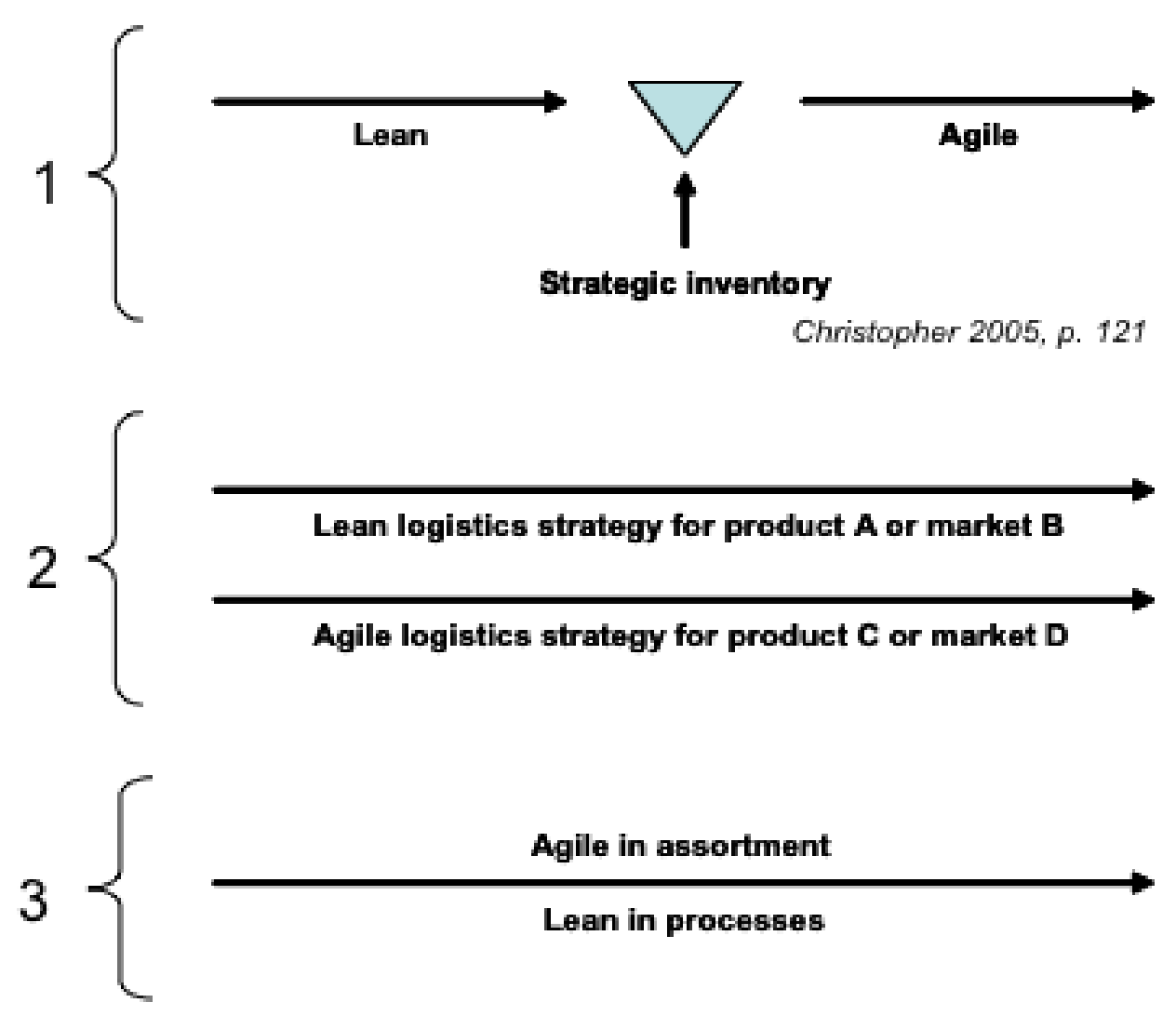

Figure 2: Different combinations of lean and agile strategies 
Characteristics of a Logistics-Based Business model

Table 1: Logistics characteristics of the external environment component

\begin{tabular}{|l|l|l|l|}
\hline Characteristics & Bama & Clas Ohlson & Dustin \\
\hline $\begin{array}{l}\text { Multiple generic } \\
\text { strategies }\end{array}$ & $\begin{array}{l}\text { Accomplished by a } \\
\text { decentralised } \\
\text { organisational } \\
\text { structure on the } \\
\text { customer side, and } \\
\text { centralised } \\
\text { structure on the } \\
\text { supplier side. }\end{array}$ & $\begin{array}{l}\text { Accomplished } \\
\text { through a } \\
\text { combination of } \\
\text { supplier and own } \\
\text { brands giving "good } \\
\text { value for money", } \\
\text { prime store } \\
\text { locations, and } \\
\text { service offerings. }\end{array}$ & $\begin{array}{l}\text { Focus on speed in the } \\
\text { supply chain, enabling } \\
\text { high availability and } \\
\text { low prices. } \\
\text { Management of } \\
\text { relationships in the } \\
\text { entire supply chain. }\end{array}$ \\
\hline $\begin{array}{l}\text { Utilisation of the } \\
\text { entire supply } \\
\text { chain }\end{array}$ & $\begin{array}{l}\text { Management of } \\
\text { multiple suppliers } \\
\text { in different regions } \\
\text { as a means to } \\
\text { secure supply. }\end{array}$ & $\begin{array}{l}\text { Long term } \\
\text { collaboration/agree } \\
\text { ments with 1st and } \\
\text { 2nd tier suppliers. }\end{array}$ & $\begin{array}{l}\text { Management of } \\
\text { relationships ranging } \\
\text { from close } \\
\text { collaboration to arms- } \\
\text { length agreements, } \\
\text { with 1st and 2nd tier } \\
\text { suppliers. }\end{array}$ \\
\hline $\begin{array}{l}\text { A combination of } \\
\text { lean and agile } \\
\text { strategies }\end{array}$ & $\begin{array}{l}\text { Standardised } \\
\text { processes but } \\
\text { many different } \\
\text { suppliers. }\end{array}$ & $\begin{array}{l}\text { Standardised } \\
\text { processes but ability } \\
\text { to ramp up sales and } \\
\text { deliveries to new } \\
\text { stores in new } \\
\text { regions. }\end{array}$ & $\begin{array}{l}\text { Standardised } \\
\text { processes and closely } \\
\text { connected to } \\
\text { suppliers, which } \\
\text { enables fast deliveries } \\
\text { and high availability. }\end{array}$ \\
\hline
\end{tabular}


Characteristics of a Logistics-Based Business model

Table 2: Logistics characteristics of the internal factor component

\begin{tabular}{|l|l|l|l|}
\hline Characteristics & Bama & Clas Ohlson & Dustin \\
\hline $\begin{array}{l}\text { Well organised and } \\
\text { simple operational } \\
\text { logistics processes }\end{array}$ & $\begin{array}{l}\text { Distribution } \\
\text { routines where the } \\
\text { need for simplicity } \\
\text { often overrides } \\
\text { more advanced } \\
\text { technical solutions. }\end{array}$ & $\begin{array}{l}\text { High degree of } \\
\text { standardisation in } \\
\text { the central } \\
\text { warehouse, often } \\
\text { supported through } \\
\text { advanced IT support. }\end{array}$ & $\begin{array}{l}\text { Picking and } \\
\text { packing } \\
\text { standardised but } \\
\text { performed } \\
\text { manually, } \\
\text { whereas IT is } \\
\text { used for control } \\
\text { and follow up. }\end{array}$ \\
\hline $\begin{array}{l}\text { Centralisation of } \\
\text { logistics design, } \\
\text { planning and } \\
\text { control }\end{array}$ & $\begin{array}{l}\text { Logistics controlled } \\
\text { centrally by the } \\
\text { purchasing } \\
\text { organisation, but } \\
\text { physical flow of } \\
\text { goods separated to } \\
\text { different customers. }\end{array}$ & $\begin{array}{l}\text { Highly centralised } \\
\text { planning and } \\
\text { execution of the } \\
\text { physical flow of } \\
\text { goods. }\end{array}$ & $\begin{array}{l}\text { Highly } \\
\text { centralised } \\
\text { planning and } \\
\text { execution of the } \\
\text { physical flow of } \\
\text { goods. }\end{array}$ \\
\hline $\begin{array}{l}\text { IT and logistics } \\
\text { operations } \\
\text { constitutes a } \\
\text { distinctive } \\
\text { capability }\end{array}$ & $\begin{array}{l}\text { Valuable: Advanced services improve cost efficiency as well as } \\
\text { effectiveness. } \\
\text { Rare: In-house development has made the systems unique. } \\
\text { Inimitability: The development of IT and logistics in symbiosis } \\
\text { also makes it difficult to imitate due to history dependency. In } \\
\text { addition, a socially complex combination of personal } \\
\text { relationships and human skills. }\end{array}$ \\
\hline
\end{tabular}


Characteristics of a Logistics-Based Business model

Table 3: Logistics characteristics of the offering component

\begin{tabular}{|l|l|l|l|}
\hline Characteristics & Bama & Clas Ohlson & Dustin \\
\hline $\begin{array}{l}\text { Despite commodity } \\
\text { products, flexibility } \\
\text { in logistics supports } \\
\text { a unique set of } \\
\text { offerings on the } \\
\text { market to different } \\
\text { customer segments }\end{array}$ & $\begin{array}{l}\text { Customised } \\
\text { deliveries, } \\
\text { packages, } \\
\text { branding in three } \\
\text { separate } \\
\text { distribution } \\
\text { channels to } \\
\text { different customer } \\
\text { segments. }\end{array}$ & $\begin{array}{l}\text { Offerings and a } \\
\text { supply function that } \\
\text { are managed } \\
\text { centrally to stores, } \\
\text { mail-order and } \\
\text { Internet customers. }\end{array}$ & $\begin{array}{l}\text { Products are } \\
\text { bundled with } \\
\text { services such as } \\
\text { configurations, to } \\
\text { private consumers } \\
\text { as well as company } \\
\text { customers in two } \\
\text { separate websites. }\end{array}$ \\
\hline $\begin{array}{l}\text { Multiple offerings } \\
\text { based on one single } \\
\text { operative logistics } \\
\text { platform. }\end{array}$ & $\begin{array}{l}\text { Utilises same } \\
\text { warehouses, } \\
\text { equipment and } \\
\text { personnel for the } \\
\text { different flows }\end{array}$ & $\begin{array}{l}\text { A centralised } \\
\text { warehouse with } \\
\text { standardisation of } \\
\text { bar codes, picking } \\
\text { routines etc for } \\
\text { stores as well as } \\
\text { Internet and mail } \\
\text { customers. }\end{array}$ & \begin{tabular}{l}
$\begin{array}{l}\text { One IT system and } \\
\text { standardised } \\
\text { processes are } \\
\text { supporting the } \\
\text { professional as well } \\
\text { as the consumer } \\
\text { market. }\end{array}$ \\
\hline
\end{tabular} \\
\hline
\end{tabular}


Figure 1
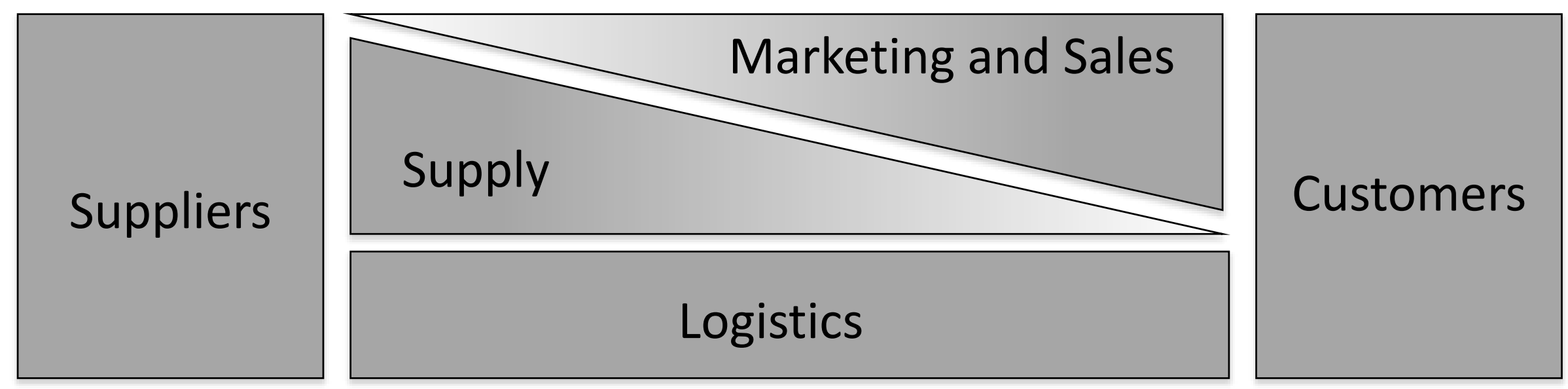


\section{Figure 2}

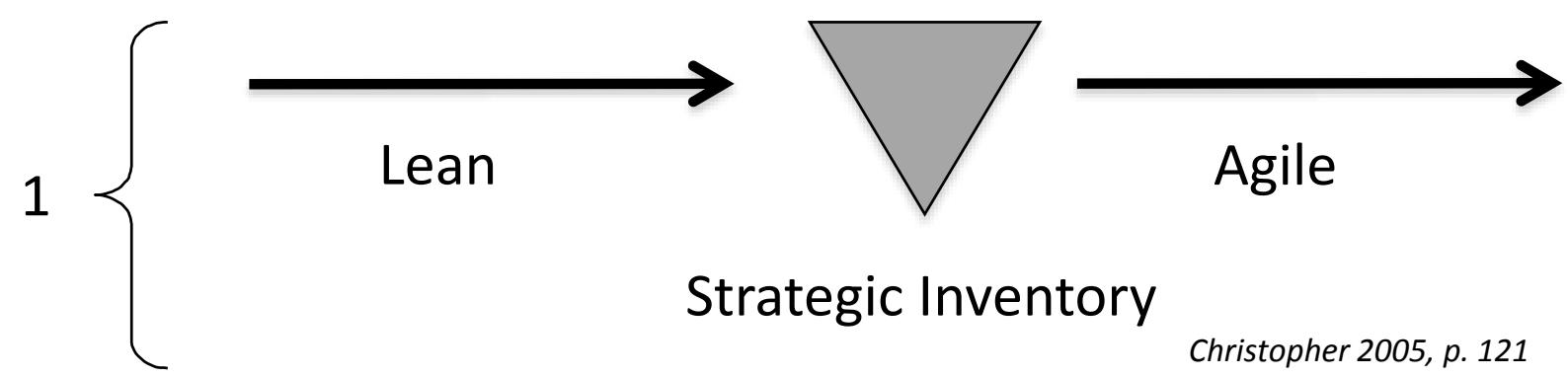

2

Lean logistics strategy for product A or market B

Agile logistics strategy for product $C$ or market $D$

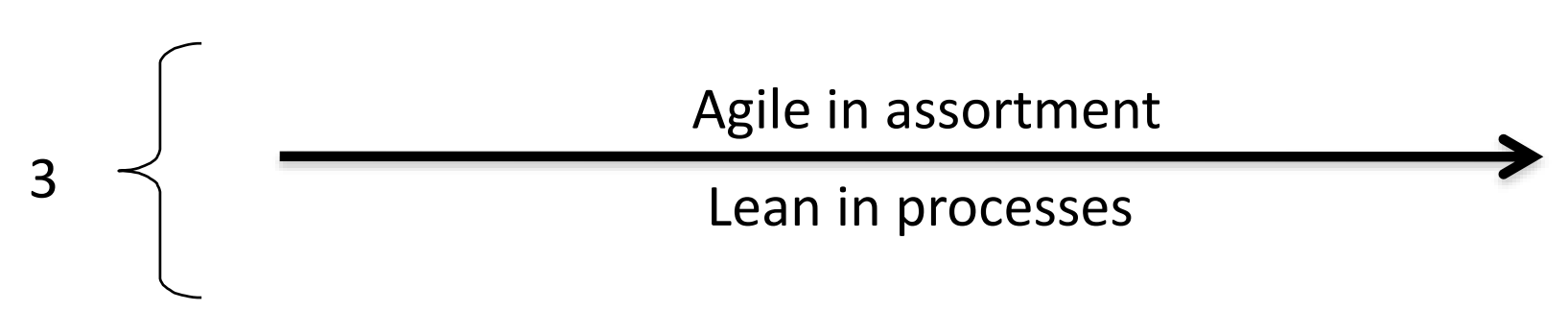




\begin{tabular}{|c|c|c|c|c|c|c|c|c|c|c|}
\hline & Afuah (2004) & Amit and Zott (2001) & $\begin{array}{l}\text { Chesbrough and } \\
\text { Rosenbloom (2002) }\end{array}$ & $\begin{array}{l}\text { Hedmanan and Kalling } \\
(2003)^{\prime}\end{array}$ & $\begin{array}{l}\text { Kindström (2005), } \\
\text { Normann (2001) }\end{array}$ & Magretta (2002) & Mahadevan (2000) & 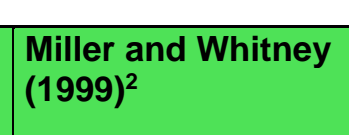 & Porter (1991) & Tikkanen et al. (2005) \\
\hline \multirow[t]{2}{*}{$\begin{array}{l}\begin{array}{l}\text { External } \\
\text { environment }\end{array} \\
\text { ent }\end{array}$} & \begin{tabular}{|l} 
Positions, (The activities \\
that the firm pursues must \\
be consistent with the \\
position of the firm on the \\
market)
\end{tabular} & $\begin{array}{l}\text { Transaction structure } \\
\text { (TThe parties that } \\
\text { particiate inth } \\
\text { exchange and the way in } \\
\text { which these parties are } \\
\text { linked and the order in } \\
\text { which exchanges take } \\
\text { place.) }\end{array}$ & $\begin{array}{l}\text { Formulating the } \\
\text { competitive strategy }\end{array}$ & Customers & Market positions & Who is the customer? & & Market (core) & $\begin{array}{l}\text { Industry structure (five } \\
\text { forces) }\end{array}$ & Business network \\
\hline & $\begin{array}{l}\text { Industry factors (The } \\
\text { activities pursued may } \\
\text { influence the competitive } \\
\text { forces and vice versa.) }\end{array}$ & & 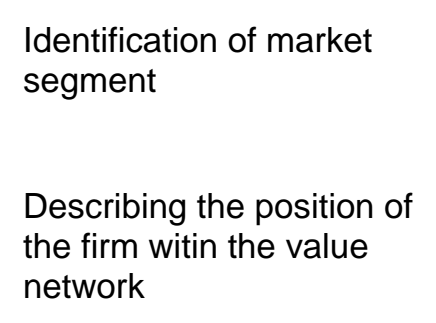 & Competitors & & $\begin{array}{l}\text { How do we make money } \\
\text { in this business? }\end{array}$ & & Mission (core) & Position & Strategy and structure \\
\hline Offering & & $\begin{array}{l}\text { Transaction content (The } \\
\text { goods or information that } \\
\text { are being exchanged, and } \\
\text { the resources and } \\
\text { capabilities that are } \\
\text { required to enable the } \\
\text { exchange.) }\end{array}$ & $\begin{array}{l}\begin{array}{l}\text { Articulation of value } \\
\text { proposition }\end{array} \\
\end{array}$ & Offering & Offering & $\begin{array}{l}\text { What does the customer } \\
\text { value? }\end{array}$ & Value stream & & & \\
\hline \multirow[t]{3}{*}{ Internal factors } & Activities & $\begin{array}{l}\text { Transaction content (The } \\
\text { goods or information that } \\
\text { are being exchanged, and } \\
\text { the resources and } \\
\text { capabilities that are } \\
\text { required to enable the } \\
\text { exchange.) }\end{array}$ & $\begin{array}{l}\text { Defining the structure of } \\
\text { the value chain within the } \\
\text { ffirm }\end{array}$ & $\begin{array}{l}\begin{array}{l}\text { Activities and } \\
\text { organisation }\end{array} \\
\end{array}$ & Operative plattorms & $\begin{array}{l}\text { What is the underlying } \\
\text { economic logic that } \\
\text { explains how we } \\
\text { deliver value to can } \\
\text { customers at an } \\
\text { appropriate cost? }\end{array}$ & Value stream & Means (core) & Activitiesvivalue system & Operations \\
\hline & \begin{tabular}{|l} 
Resources (The \\
activitities should \\
leverage the firm's \\
resources.).
\end{tabular} & $\begin{array}{l}\text { Transaction structure } \\
\text { (The parties that } \\
\text { participate in the } \\
\text { exchange and the way in } \\
\text { which these parties are } \\
\text { linked, and the order in } \\
\text { which exchanges take } \\
\text { pliace.) }\end{array}$ & $\begin{array}{l}\text { Estimating the cost } \\
\text { structure and profit } \\
\text { potential }\end{array}$ & $\begin{array}{l}\text { Supply of factor and } \\
\text { production inputs }\end{array}$ & & & Logistics stream & & $\begin{array}{l}\text { Drivers (Structural } \\
\text { determinants of } \\
\text { differences in the cost or } \\
\text { buyer value of activities or } \\
\text { groups of activities) }\end{array}$ & Finance and accounting \\
\hline & 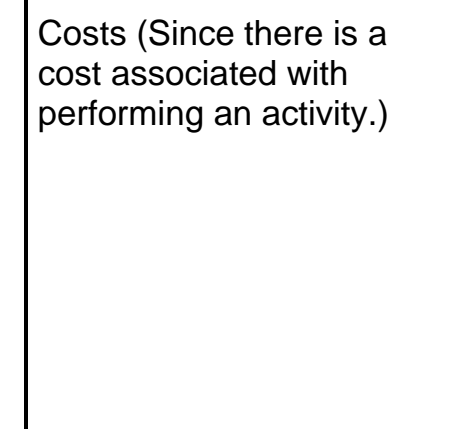 & $\begin{array}{l}\text { Transaction governance } \\
\text { (The ways in which flows } \\
\text { of information, resources, } \\
\text { and goods are controlled } \\
\text { by the relevant parties. It } \\
\text { also handles the legal } \\
\text { form of organisation and } \\
\text { the incentives for the } \\
\text { participants in } \\
\text { transactions.) }\end{array}$ & & Resources & & & Revenue stream & & & \\
\hline
\end{tabular}

1. Hedman and Kalling process-component

2. Miller and Whitney also include a number of support systems in their business model (or configuration in their terminology) 